\title{
Alterations in follicular dynamics and steroidogenic abilities induced by heat stress during follicular recruitment in goats
}

\author{
M Ozawa, D Tabayashi, T A Latief, T Shimizu, I Oshima and Y Kanai \\ Graduate School of Life and Environmental Sciences, University of Tsukuba, Tsukuba-shi, Ibaraki 305-8572, Japan \\ Correspondence should be addressed Y Kanai, Graduate School of Life and Environmental Sciences, University of Tsukuba, \\ Tsukuba-shi, Ibaraki 305-8572, Japan; Email: kanaiy@sakura.cc.tsukuba.ac.jp
}

M Ozawa is currently at the Genetic Diversity Department, National Institute of Agrobiological Sciences, 2-1-2 Kannondai, Tsukuba-shi, Ibaraki 305-8602, Japan

\begin{abstract}
We investigated the changes in follicular dynamics and steroidogenic activity during heat stress in goats. Adult female goats were exposed to heat stress at $36^{\circ} \mathrm{C}$ and $70 \%$ relative humidity for $48 \mathrm{~h}$ and then injected with prostaglandin (PG) $\mathrm{F}_{2 \alpha}$ (the time of $\mathrm{PGF}_{2 \alpha}$ injection was designated as $\mathrm{Oh}$ ). In experiment 1, every follicle greater than $\mathbf{2}$ mm in diameter was monitored by ultrasonography to investigate the follicular dynamics, and plasma concentrations of $\mathrm{FSH}$, $\mathrm{LH}$, progesterone, and oestradiol were measured from $-48 \mathrm{~h}$ to $120 \mathrm{~h}$. In experiment 2 , the follicles were recovered from the goats at $48 \mathrm{~h}$, and the concentration of oestradiol, the aromatase activity, and the $\mathrm{LH}$ receptor level in the follicles were determined. In control (non-heatstressed) goats, ovulatory follicles were mainly recruited from $-24 \mathrm{~h}$ to $\mathrm{oh}$, whereas no follicles recruited during that period were ovulated in the heat-stressed goats. The timing of the recruitment of ovulatory follicles was delayed by heat stress by approximately $24 \mathrm{~h}$. The plasma concentration of oestradiol in the heat-stressed goats was significantly lower from 36 to $54 \mathrm{~h}$ compared with the controls, although the concentrations of FSH and progesterone did not differ between the treatments. In addition, the concentration of oestradiol, the aromatase activity, and the LH receptor level in the follicles from heat-stressed goats were significantly lower compared with the controls. These results indicate that heat stress during follicular recruitment suppresses subsequent growth to ovulation, accompanied by decreased LH receptor level and oestradiol synthesis activity in the follicles.

Reproduction (2005) $129621-630$
\end{abstract}

\section{Introduction}

Low fertility is widely observed in domestic animals during the summer (Ingraham et al. 1974, Gwazdauskas et al. 1975). This problem has recently been exacerbated by increases in livestock productivity and the concurrent rise in metabolic heat production. In lactating cows, hyperthermia can occur at ambient temperatures as low as $27^{\circ} \mathrm{C}$ (Berman et al. 1985) and causes a decreased rate of conception (Udompraset \& Williamson 1987). Although low summer fertility syndrome is attributed to multiple mechanisms (reviewed by Hansen et al. 2001), alteration of follicular dynamics, including steroidogenic ability, is a major factor in the development of the syndrome (Badinga et al. 1993, Trout et al. 1998, Wolfenson et al. 2000).

During the 1990s, ultrasonographic techniques were developed using the intrarectal approach to visualize ovaries (Fortune et al. 1991, Griffin \& Ginther 1992), providing a direct and noninvasive means of monitoring heat-stressinduced follicular changes. It has been reported that heat stress suppresses the functions of the largest follicle, i.e. the dominant follicle. In lactating cows under heat stress, the size of the dominant follicle is reduced during the first and second follicular waves (Badinga et al. 1993, Wilson et al. 1998a,b), and the number of follicles of the next largest size is increased (Wolfenson et al. 1995). In contrast, discrepancies still exist between previous studies concerning follicular recruitment under heat stress; it was found that heat stress caused either a decrease (Wolfenson et al. 1995) or an increase (Trout et al. 1998) in the emergence of small follicles (2-5 $\mathrm{mm}$ in diameter). In addition, although it was reported that heat stress caused a decrease in the oestradiol concentration of the fluid of the dominant follicle (Wolfenson et al. 1997), the steroidogenic activity in small and medium follicles under heat stress has been poorly investigated.

Circulating concentrations of gonadotrophin, which plays an important role in regulating follicular dynamics, are also altered by heat stress. A previous study found that heat stress caused an increase in the plasma follicle-stimulating hormone $(\mathrm{FSH})$ concentration in cows (Roth et al. 
2000). On the other hand, conflicting findings concerning the effect of heat stress on plasma luteinizing hormone (LH) have been reported; heat stress has been reported to cause the plasma LH concentration in cows to decrease (Madan \& Johnson 1973, Miller \& Alliston 1974), remain unchanged (Gwazdauskas et al. 1981, Rosenberg et al. 1982), or increase (Roman-Ponce et al. 1981). More recently, Kanai et al. (1995) found that heat stress did not change the pituitary LH secretion in long-day-treated anoestrous goats that were injected with exogenous gonadotrophin-releasing hormone $(\mathrm{GnRH})$ to induce artificial LH pulses, whereas it reduced the follicular responsiveness to $\mathrm{LH}$. Follicular $\mathrm{LH}$ responsiveness is attributed to the expression of $\mathrm{LH}$ receptors on the follicles (Webb \& England 1982). Therefore, it appears probable that heat stress induces alterations in the follicular LH receptors. In the present study, we investigated the follicular alterations induced by heat stress during follicular recruitment by monitoring (i) follicular dynamics using ultrasonography; (ii) plasma concentrations of LH, FSH, oestradiol, and progesterone; and (iii) follicular steroidogenic activity and LH receptor expression in heat-stressed and control goats.

\section{Materials and methods}

\section{Animals}

The 3-5-year-old female Shiba goats (Capra hircus) used in this study were housed in an environmental chamber at $25^{\circ} \mathrm{C}$ and $50 \%$ relative humidity (RH) with a 12-h light/12-h dark photoperiod (lights on at $0800 \mathrm{~h}$ ) and were fed alfalfa-hay cubes $(25 \mathrm{~g} / \mathrm{kg}$ body weight per day). Water and mineralized licks (Koen; Nippon Zenyaku Kogyo Co., Hukushima, Japan) were available ad libitum. All experimental protocols and animal handling procedures were reviewed and approved by the Animal Care and Use Committee of the University of Tsukuba.

\section{Synchronization of oestrous cycles and temperature treatment}

The plasma progesterone concentrations of the goats were assayed to determine the phase of the oestrous cycle, and the oestrous cycles were subsequently synchronized using a single intramuscular injection of $0.5 \mathrm{ml}$ prostaglandin (PG) $\mathrm{F}_{2 \alpha}$ (Panacelan-Hi; Fine Chemical Technology Co., Toyama, Japan) administered 8-10 days following the detection of oestrus. The time of the $\mathrm{PGF}_{2 \alpha}$ injection was designated $0 \mathrm{~h}$, and the goats were heat stressed in an environmental chamber at $36^{\circ} \mathrm{C}$ and $70 \% \mathrm{RH}$ from -48 to $0 \mathrm{~h}$. The control goats remained at $25^{\circ} \mathrm{C}$ and $50 \% \mathrm{RH}$.

\section{Monitoring of rectal temperature, respiration and heart rates, and water and feed intake}

The rectal temperature of each goat was measured at 6-h intervals from -72 to $24 \mathrm{~h}$ with a Thermistor instrument (D611; Takara Thermistor Co., Tokyo, Japan). Respiration and heart rate were counted once daily during the experimental period. The water and feed were weighed each day, and daily intakes were calculated. All measurements were made inside the environmental chamber.

\section{Ultrasound evaluation of follicular dynamics}

Follicular dynamics were observed once a day from -48 to $120 \mathrm{~h}$ by imaging using a B-mode scanner (SSD-630; Aloka Co., Tokyo, Japan) with a $7.5 \mathrm{MHz}$ Transrectum Electronic Linear Probe (UST-660-7.5; Aloka Co.). Every observed follicle of $\geq 2 \mathrm{~mm}$ in diameter was recorded. We preliminarily observed that the mean diameter of the ovulatory follicle was $5.1 \pm 0.1 \mathrm{~mm}$ (data not shown). In this study, therefore, the follicles were classified by diameter as small $(2-3.4 \mathrm{~mm})$, medium $(3.5-4.9 \mathrm{~mm})$, or large $(\geq 5 \mathrm{~mm})$, according to our preliminary examination and a previous report on sheep by Carson et al. (1979). On each examination, the relative location of follicles and their diameters were recorded to determine the patterns of recruitment, growth, and regression of individual follicles. Follicular recruitment was identified as the day of emergence of new small follicles (Ravindra et al. 1994). Ovulation was determined using three criteria: (i) the disappearance of a large follicle, (ii) the subsequent development of a corpus luteum within 3 days, and (iii) an increase of the plasma progesterone concentration above $1 \mathrm{ng} / \mathrm{ml}$.

\section{Sampling of blood and follicles}

Blood samples $(3-8 \mathrm{ml})$ were collected from the jugular vein once daily from -48 to $0 \mathrm{~h}$ and at 6 -h intervals from 0 to $144 \mathrm{~h}$ to determine plasma progesterone, oestradiol, $\mathrm{FSH}$, and $\mathrm{LH}$ levels. For monitoring of pulsatile $\mathrm{LH}$ secretions, blood samples were collected at a 6-min interval from 36 to $40 \mathrm{~h}$. The samples were centrifuged, and the supernatants were stored at $-20^{\circ} \mathrm{C}$ until assayed for each hormone ( $n=6$ in each group). In addition, another six ovariectomized $(\mathrm{OVX})$ goats were monitored for $\mathrm{LH}$ pulses according to the method described by Tanaka et al. (1994), with some modifications. In brief, OVX goats were implanted subcutaneously with capsules $(3.35 \mathrm{~mm}$ inner diameter, $4.65 \mathrm{~mm}$ outer diameter, $4.0 \mathrm{~mm}$ length; Dow Corning Toray Silicone Co., Tokyo, Japan) containing $0.1 \mathrm{~g}$ oestradiol for 5 days, or implanted with capsules made of Silastic sheet $(50 \times 75 \mathrm{~mm}$; Dow Corning Toray Silicone Co.) containing $1.0 \mathrm{~g}$ progesterone additionally with oestradiol capsules for 5 days. Blood samples were recovered 1 day before steroid implantation (without steroids), 5 days after oestradiol implantation (E implantation), or 5 days after oestradiol and progesterone implantation $(\mathrm{E}+\mathrm{P}$ implantation), to monitor the pulsatile $\mathrm{LH}$ secretions. The pulses were identified by the method as described by Merriam \& Wachter (1982).

The ovaries were surgically recovered at $48 \mathrm{~h}$ from eight other goats $(n=4$ each in the control and heat-stress 
groups). Every follicle that was recruited from -24 to $0 \mathrm{~h}$ and that had a diameter of $2 \mathrm{~mm}$ or larger was collected from the ovaries and classified by size. The follicles, grouped by size, were minced with ophthalmic scissors in $1 \mathrm{ml}$ PBS in plastic centrifuge tubes held on ice and then centrifuged at $1000 \mathrm{~g}$ for $15 \mathrm{~min}$. The supernatants containing the follicular fluids were assayed for hormone levels. The precipitates containing the cumulus and theca cells were washed with M199 medium (Sigma Chemical Co., St Louis, MO, USA) and assayed for aromatase activity and $\mathrm{LH}$ receptor content.

\section{Plasma and follicular fluid hormone assays}

The plasma concentrations of $\mathrm{FSH}$ and $\mathrm{LH}$ were assayed by double-antibody RIA as described by Araki et al. (2000) for FSH and Mori \& Kano (1984) for LH. Rabbit anti-sheep FSH serum (NIAMDD-anti-oFSH-1) and rabbit anti-sheep $\mathrm{LH}$ serum (YM-18) were used as the primary antibodies. Purified sheep FSH (NIAMDD-oFSH-RP-1) and $\mathrm{LH}$ (NIAMDD-oLH-24) were used as reference standards and as iodinated ligands. The radioactivity was counted on a gamma counter (ARC-380; Aloka Co.). The sensitivities of the assays were $0.05 \mathrm{ng} / \mathrm{ml}$, and the inter-assay coefficients of variation were $12.0 \%$ for $\mathrm{FSH}$ and $11.3 \%$ for $\mathrm{LH}$.

The progesterone and oestradiol concentrations in the plasma and follicular fluid samples were measured by single-antibody RIA in duplicate. Rabbit anti-progesterone-11 $\alpha$-BSA serum or rabbit anti-oestradiol-6-CMO-BSA serum was used as antibody, and $\left[1,2,6,7-{ }^{3} \mathrm{H}\right]$ progesterone $(103 \mathrm{Ci} / \mathrm{mmol})$ or $\left[2,4,6,7,16,17-{ }^{3} \mathrm{H}\right]$ oestradiol $(151 \mathrm{Ci} /$ mmol; both from Amersham International) were used as the radiolabeled hormone. For the progesterone assay, $300 \mu \mathrm{l}$ of each sample was added to $3 \mathrm{ml}$ hexane, mixed, and centrifuged. The samples were separated into $1 \mathrm{ml}$ aliquots and dried under $\mathrm{N}_{2}$ gas. Then $100 \mu \mathrm{l}$ rabbit anti-progesterone serum diluted 1:6000 in 0.01 M PBS containing $0.1 \%(\mathrm{w} / \mathrm{v})$ gelatin (PBS-gel), $100 \mu \mathrm{l}$ radiolabeled progesterone (20000 d.p.m. in PBS), and $500 \mu$ l PBS-gel were added to each sample tube and incubated at $4{ }^{\circ} \mathrm{C}$ for $24 \mathrm{~h}$. After incubation, $200 \mu$ l dextran-coated charcoal solution (prepared by mixing equivalent volumes of $0.5 \%(\mathrm{w} / \mathrm{v})$ Norit A and $0.05 \%$ (w/v) dextran solutions; Sigma Chemical Co.) was added and reacted for $15 \mathrm{~min}$. The samples were centrifuged at $1000 \mathrm{~g}$ for $15 \mathrm{~min}$ at $4{ }^{\circ} \mathrm{C}$; $500 \mu \mathrm{l}$ of each supernatant was then transferred to a vial containing $4.5 \mathrm{ml}$ scintillation fluid and counted on a scintillation counter (LSC-6000; Aloka Co.). For the oestradiol assay, $2 \mathrm{ml}$ of each sample was added to $10 \mathrm{ml}$ benzene and dried under $\mathrm{N}_{2}$ gas. The residues were redissolved in $1.2 \mathrm{ml}$ PBS-gel and separated into $500 \mu \mathrm{l}$ aliquots. Rabbit anti-oestradiol antibody (diluted 1:44000 in PBS-gel; $100 \mu \mathrm{l}$ ) and $100 \mu \mathrm{l}$ labeling hormone (20000 d.p.m. in PBS) were added, and the procedure described above for the progesterone assay was followed to determine the oestradiol concentration. The sensitivities of the progesterone and oestradiol assays were 1 and $4 \mathrm{pg} / \mathrm{ml}$. The inter- and intra-assay coefficients of variation for progesterone were 12.3 and $7.1 \%$, and for oestradiol were 11.1 and $7.9 \%$.

\section{Aromatase activity assay and $L H$ receptor assay}

The aromatase activity in the follicles was assayed using the methods described by Robert et al. (1980) and Thatcher et al. (1991). In brief, minced follicle samples were added to $4 \mathrm{ml} \mathrm{M199}$ medium containing $9.3 \mathrm{mM}$ $\left[1 \beta, 2 \beta-{ }^{3} \mathrm{H}\right]$ testosterone $(0.5 \mu \mathrm{Ci} / \mathrm{mmol} ; \quad \mathrm{New}$ England Nuclear, Boston, MA, USA) and incubated at $38.5^{\circ} \mathrm{C}$ in $5 \%(\mathrm{v} / \mathrm{v}) \mathrm{CO}_{2}$ for $3 \mathrm{~h}$. After incubation, sample tubes were centrifuged at $1000 \mathrm{~g}$ for $15 \mathrm{~min}$ at $4{ }^{\circ} \mathrm{C}$, and $1 \mathrm{ml}$ of the supernatants were transferred into another tube containing $200 \mu \mathrm{l}$ 25\% (w/v) Norit SX-II solution (Wako Pure Chemical Industries, Osaka, Japan) and incubated at $4{ }^{\circ} \mathrm{C}$ for $2 \mathrm{~h}$. Subsequently, tubes were centrifuged at $1000 \mathrm{~g}$ for $15 \mathrm{~min}$ at $4{ }^{\circ} \mathrm{C}$, and $500 \mu \mathrm{l}$ of supernatants were transferred into vials with $4 \mathrm{ml}$ emulsion scintillator, and the scintillations were measured using a scintillation counter (Aloka Co.). After the measurement of the aromatase activity, the samples were washed in $3 \mathrm{ml}$ PBS containing $1 \%(\mathrm{w} / \mathrm{v})$ BSA (PBS/BSA) and centrifuged at $1000 \mathrm{~g}$ for $15 \mathrm{~min}$ at $4{ }^{\circ} \mathrm{C}$. The precipitates were used to determine the $\mathrm{LH}$ receptor levels using the method described by Kawate et al. (1989). In brief, $1 \mathrm{ml}$ PBS/BSA was added to tubes containing sample precipitates, and homogenized on ice. Each homogenate was transferred to another tube with $100 \mu{ }^{125}$ I-labelled human chorionic gonadotrophin (300 000 d.p.m.) and incubated at $25^{\circ} \mathrm{C}$ for $24 \mathrm{~h}$. Then, $2 \mathrm{ml}$ assay buffer (PBS/BSA containing $0.5 \%(\mathrm{w} / \mathrm{v})$ silica gel) were added into tubes, and centrifuged at $1000 \mathrm{~g}$ for $30 \mathrm{~min}$ at $4{ }^{\circ} \mathrm{C}$ and the supernatants were removed. Then another $2 \mathrm{ml}$ assay buffer was added and centrifuged again. Supernatants were removed and the radioactivities in the precipitates were counted using a gamma counter (Aloka Co.). The inter- and intra-assay coefficients of variation for aromatase were 7.3 and $6.7 \%$, and for LH receptor were 11.5 and $7.6 \%$, respectively.

\section{Statistical analysis}

The data are expressed as means \pm S.E.M. The number of recruited follicles, rectal temperature, respiration and heart rates, water and feed intake, aromatase activity, LH receptor levels, and concentrations of oestradiol and progesterone in the follicular fluid were analyzed using Student's $t$-test. Changes in plasma oestradiol, progesterone, $\mathrm{LH}$, and $\mathrm{FSH}$ concentrations were analyzed using ANOVA for repeated measures (Gill \& Hafs 1971). When a significant effect was detected with ANOVA, the significance of the difference between means was determined by Duncan's multiple range test. The percentages of follicles that eventually ovulated were arc-sine transformed and then analyzed using Student's $t$-test. 


\section{Results}

\section{General response to heat stress}

The general responses to heat stress in the goats are shown in Table 1. The average rectal temperature of the goats in the heat-stress group was significantly increased compared with that of the controls $(P<0.001)$. The respiration rate, water and feed intakes $(P<0.001)$, and heart rate $(P<0.01)$ were significantly different between the control and heat-stress groups. During the treatment period, no parameters differed significantly among the groups. In addition, none of the parameters differed before and after the heat exposure compared with the control (data not shown).

\section{Effects of heat stress on follicular dynamics and ovulation}

The numbers of recruited follicles and the percentages of follicles that eventually ovulated observed during the experiment are presented in Table 2. Follicles were recruited throughout the experimental period in both the control and heat-stress groups. The number of recruited follicles was increased $(P<0.05)$ at $24 \mathrm{~h}$ and decreased $(P<0.01)$ at $120 \mathrm{~h}$ in the heat-stressed animals compared with the controls. In the control group, the follicles that eventually ovulated were recruited from -48 to $24 \mathrm{~h}$, with most observed from -24 to $0 \mathrm{~h}$. In contrast, no follicles that eventually ovulated were recruited from -24 to $0 \mathrm{~h}$ in the heat-stress group, and this difference was significant at $0 \mathrm{~h}(P<0.05)$. The ratio of follicles that eventually ovulated at $24 \mathrm{~h}$ was significantly higher $(P<0.05)$ in the heat-stress group compared with the controls. Ovulation

Table 1 Rectal temperature, respiration rate, heart rate, water intake, and feed intake in goats under control and heat-stress conditions. Data are expressed as the mean \pm S.E.M. of six replicates.

\begin{tabular}{lcc}
\hline Parameter & Control & Heat-stressed \\
\hline Rectal temperature $\left({ }^{\circ} \mathrm{C}\right)$ & $39.0 \pm 0.0$ & $40.6 \pm 0.2 * * *$ \\
Respiration ratio $($ breaths/min $)$ & $33.8 \pm 1.2$ & $190.3 \pm 3.6^{* * *}$ \\
Heart ratio $(\mathrm{beats} / \mathrm{min})$ & $74.5 \pm 1.7$ & $64.2 \pm 2.3^{* *}$ \\
Water intake $(\mathrm{ml} / \mathrm{kg} \mathrm{BW} /$ day $)$ & $55.7 \pm 3.3$ & $361.8 \pm 40.3^{* * *}$ \\
Feed intake $(\mathrm{ml} / \mathrm{kg} \mathrm{BW} /$ day) & $24.6 \pm 0.4$ & $9.6 \pm 1.7^{* * *}$ \\
\hline
\end{tabular}

**, ***Significantly different from control $(P<0.01$ and $P<0.001$ respectively) by Student's $t$-test. BW, Body weight. tended to be delayed in heat-stressed goats $(128.0 \pm 4.4 \mathrm{~h})$ compared with that in controls $(116.0 \pm 2.7 \mathrm{~h})$. The growth rates of follicles, which were recruited during -24 to $0 \mathrm{~h}$, did not differ between treatments at small size $(0.75 \pm 0.25 \mathrm{~mm} /$ day in the control group versus $0.71 \pm 0.06 \mathrm{~mm} /$ day in the heat-stress group) or middle size $(0.74 \pm 0.07 \mathrm{~mm} /$ day in the control group versus $0.76 \pm 0.05 \mathrm{~mm} /$ day in the heat-stress group). The follicles did not grow into the large size in the heat-stress group (large-size follicles in the control group were $0.75 \pm 0.03 \mathrm{~mm} /$ day). Mean follicle numbers in each size class during the experiment are shown in Fig. 1, and representative patterns of follicular growth from one of six control and heat-stressed goats are shown in Fig. 2.

\section{Effects of heat stress on plasma hormone concentrations}

The patterns of fluctuation of progesterone, oestradiol, LH, and FSH in the plasma are illustrated in Fig. 3. Progesterone concentrations rapidly decreased after the $\mathrm{PGF}_{2 \alpha}$ injection and remained low throughout the remainder of the experimental period in both groups. Oestradiol concentrations increased after the $\mathrm{PGF}_{2 \alpha}$ injection. The peak concentration of oestradiol was observed at $54 \mathrm{~h}$ in the control group and at $72 \mathrm{~h}$ in the heat-stress group. The patterns of the oestradiol levels differed significantly $(P<0.05)$ between the control and heat-stress groups, and the concentrations in the heat-stress group were significantly lower $(P<0.05)$ from 36 to $54 \mathrm{~h}$ compared with the control group. The peak value of the LH surge did not differ between the two groups $(P>0.05)$; however, the surge was significantly delayed by approximately $21 \mathrm{~h}$ in the heat-stress group compared with the controls $(83.0 \pm 2.5$ and $62.0 \pm 2.0 \mathrm{~h}$, respectively; $P<0.05)$. No significant differences were detected in the patterns of the FSH concentrations between the control and the heatstress group. The characteristics of pulsatile $\mathrm{LH}$ secretion are expressed in Table 3. The frequency of the LH pulse tended to decrease in the intact goat that was heat stressed compared with the control, whereas no significant difference was detected between heat stress and control in the OVX goat that had $\mathrm{E}$ implantation or $\mathrm{E}+\mathrm{P}$ implantation,

Table 2 Numbers of recruited follicles and percentages of eventually ovulatory follicles recruited at each time during the experiment in goats under control and heat-stress conditions. Data are expressed as the mean \pm S.E.M. of six replicates.

\begin{tabular}{|c|c|c|c|c|c|c|c|c|c|}
\hline & \multirow[b]{2}{*}{ Treatment } & \multicolumn{8}{|c|}{ Hours post $\mathrm{PGF}_{2 \alpha}$ injection } \\
\hline & & -48 & -24 & 0 & 24 & 48 & 72 & 96 & 120 \\
\hline \multirow{2}{*}{$\begin{array}{l}\text { Number of } \\
\text { recruited follicles }\end{array}$} & Control & $5.2 \pm 0.9$ & $2.8 \pm 0.7$ & $1.8 \pm 0.6$ & $1.7 \pm 0.6$ & $1.5 \pm 0.3$ & $0.8 \pm 0.4$ & $2.7 \pm 1.3$ & $4.2 \pm 0.5$ \\
\hline & Heat & $3.7 \pm 0.6$ & $2.5 \pm 0.6$ & $2.2 \pm 0.7$ & $3.8 \pm 0.5 *$ & $2.3 \pm 0.6$ & $2.0 \pm 0.4$ & $1.8 \pm 0.2$ & $1.3 \pm 0.6^{* *}$ \\
\hline \multirow{2}{*}{$\begin{array}{l}\text { Percentage of } \\
\text { eventually-ovulatory follicles }\end{array}$} & Control & $26.5 \pm 15.3$ & $29.2 \pm 16.4$ & $61.1 \pm 15.3$ & $16.7 \pm 16.7$ & $0.0 \pm 0.0$ & $0.0 \pm 0.0$ & $0.0 \pm 0.0$ & $0.0 \pm 0.0$ \\
\hline & Heat & $8.9 \pm 5.9$ & $0.0 \pm 0.0$ & $0.0 \pm 0.0 *$ & $61.7 \pm 13.7 *$ & $3.3 \pm 3.3$ & $0.0 \pm 0.0$ & $0.0 \pm 0.0$ & $0.0 \pm 0.0$ \\
\hline
\end{tabular}

$*, * *$ Significantly different from control $(P<0.05$ and $P<0.01$, respectively). Numbers and arc-sine-transformed percentages were analysed by Student's $t$-test. 


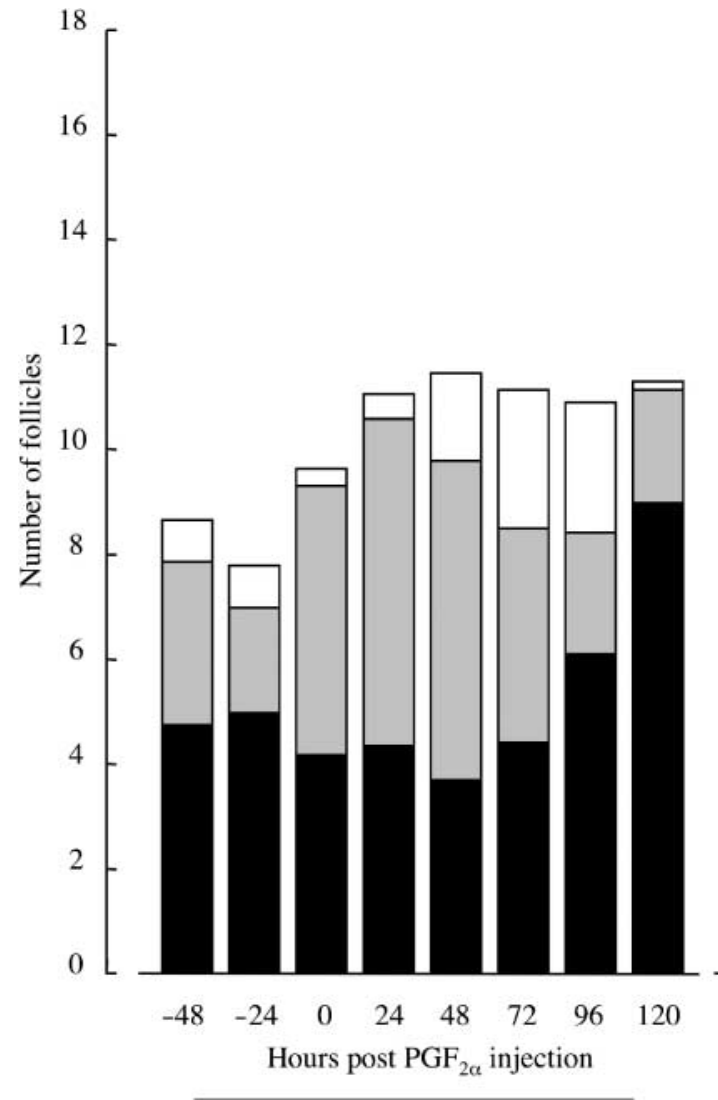

Control

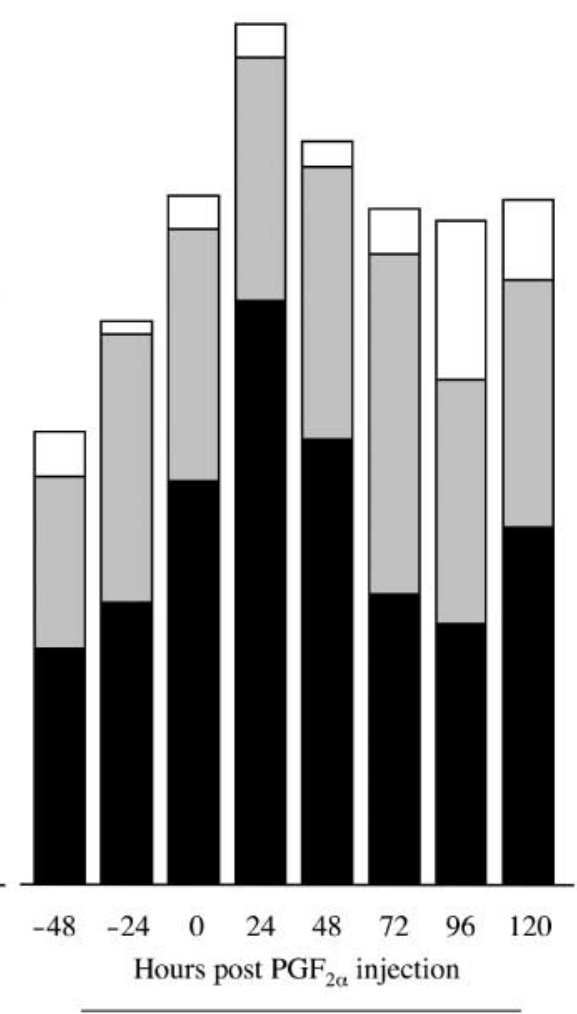

Heat stress
Figure 1 Total follicle numbers of small size $(2.0-3.4 \mathrm{~mm}$; black bars), middle size (3.5-4.9 mm; shaded bars), and large size (>5 mm; white bars) in the control group and heat-stress group. The follicles were monitored during the experimental period using an ultrasonic scanner. Values are expressed as the means from six replicates. or in the without-steroid group in each pulsatile characteristic $(P>0.05)$.

\section{Effects of heat stress on $L H$ receptor content, steroids levels, and aromatase activity in follicles}

The levels of LH receptor, aromatase activity, oestradiol, and progesterone at $48 \mathrm{~h}$ in the follicles of each size are presented in Fig. 4. No follicles recruited from -24 to $0 \mathrm{~h}$ grew to large size in the heat-stress group, and no significant differences between the heat-stress and control groups were found for any parameter in the small follicles. In the medium follicles, however, a number of differences were found. Compared with the control condition, heat stress significantly $(P<0.05)$ reduced the $\mathrm{LH}$ receptor content $(229.7 \pm 33.8$ versus $132.6 \pm 24.0 \mathrm{fmol} /$ follicle $)$, aromatase activity $(152.1 \pm 25.0$ versus $88.2 \pm 17.6 \mathrm{pg}$ oestradiol/follicle per $3 \mathrm{~h}$ ), and oestradiol concentration (95.4 \pm 13.7 versus $63.6 \pm 0.7 \mathrm{ng} /$ follicle). The progesterone concentration did not differ significantly between the two groups $(7.9 \pm 0.4$ versus $8.6 \pm 0.8 \mathrm{ng} /$ follicle in the control and heat-stress groups, respectively).

\section{Discussion}

In this study, we determined the changes in follicular dynamics and steroidogenic activity in goats under heat stress. The results indicated that heat stress during follicular recruitment reduced the steroidogenic activity in follicles, as shown by the decreased concentration of oestradiol and low aromatase activity. Our data also indicated that all follicles that were exposed to heat stress during recruitment regressed before attaining a large size and were never ovulated, although the number of follicles recruited during heat exposure did not change compared with that in the control goats.

It has been shown that low summer fertility occurs in many mammalian species, especially in domestic animals because of their heightened productivity (Hansen et al. 2001, Rensis \& Scaramuzzi 2003). Several causes of reduced summer fertility have been reported, including lowered oocyte competence (Al-Katanani et al. 2001, Zeron et al. 2001), reduced expression of oestrus (Hansen \& Aréchiga 1999), and early embryonic death (Ealy et al. 1993, Ozawa et al. 2002). In addition, alteration of follicular functions during heat stress, including follicular dynamics and steroidogenic activity, has been described as a major factor in reduced summer fertility (Wolfenson et al. 1995, Wilson et al. 1998a,b). In the case of goats, although a number of studies have monitored ovarian dynamics using ultrasonography (Menchaca \& Rubianes 2002, Medan et al. 2003), or analyzed the changes in ovarian steroids and gonadotrophin secretions during the 
(A)

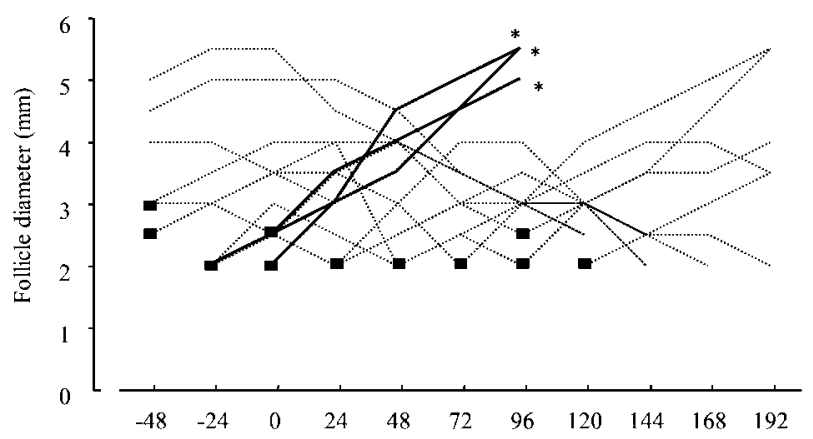

(B) Heat

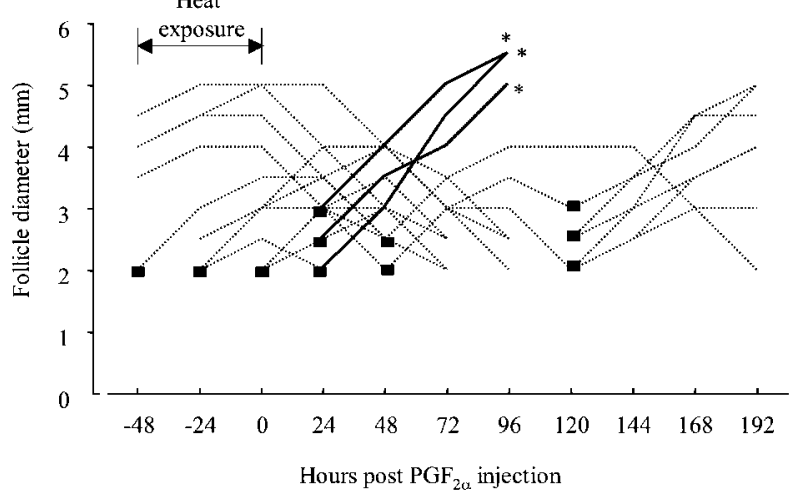

Figure 2 Representative growth patterns of individual follicles from goats in (A) the control group and (B) the heat-stress group. Female goats were either exposed to heat stress or not stressed (control group) for $48 \mathrm{~h}$ ( -48 to $0 \mathrm{~h}$ ) prior to intramuscular injection of $\mathrm{PGF}_{2 \alpha}$ at $0 \mathrm{~h}$. Follicular growth was observed using an ultrasonic scanner. $\mathbf{m}$, Emergence of a recruited follicle; *, ovulation.

follicular phase under neutral temperature conditions (de Castro et al. 1998, Menchaca \& Rubianes 2002), no reports have been published, to our knowledge, concerning follicular dynamics and steroidogenic activities under heat stress. Our present results, therefore, provide additional information on how to understand the effects of heat stress on follicular functions, not only in the goat as a domestic animal, but also as a ruminant experimental animal model.

Several studies have reported that plasma oestradiol concentrations are decreased by heat stress in cows (Wolfenson et al. 1995, 1997, Wilson et al. 1998a,b). The results in the present study also indicated that heat stress during follicular recruitment reduced the plasma oestradiol concentration during the 18 -h period from 36 to $54 \mathrm{~h}$. The decrease in plasma oestradiol could be related to the significant decrease in oestradiol concentration in the fluid of medium follicles caused by heat stress. Oestradiol production is regulated by aromatase activity in granulosa cells (Dorrington et al. 1975, Erickson \& Hsufh 1978). In the cow, aromatase activity is drastically increased in medium-sized follicles $(4-8 \mathrm{~mm}$ in diameter), accompanied by an increase in the oestradiol concentration in the follicles (McNatty et al. 1984). The results obtained in the present study showed that the aromatase activity in the medium follicles was lower in the heatstress group than in the control group. The reductions in oestradiol concentration and aromatase activity in the follicles are in agreement with a previous report showing that, in cows, the oestradiol concentration and aromatase activity in the dominant follicle are significantly lower in summer than in the same size follicle in autumn (Badinga et al. 1993). Thus, it is suggested that decreased aromatase activity under heat stress suppresses oestradiol synthesis in oestrogenic follicles. In contrast, the aromatase activity and fluid oestradiol concentration in the small follicles remained low and a significant difference was not detected between the heat stress and control groups. McNatty et al. (1984) reported that the aromatase activity in pre-oestrogenic follicles remains low and the oestradiol synthesis activity is insubstantial. Therefore, it is possible that the effect of heat stress on oestradiol synthesis activity might be less evident in small follicles, although the follicular size that is the boundary of the pre- to post-oestrogenic phases will be strongly required in the goat.

Aromatase activity in granulosa cells is highly regulated by FSH (Dorrington et al. 1975, Erickson \& Hsufh 1978). Plasma FSH concentrations were not altered by heat stress in the present study. However, a recent study in immature rats indicated that heat stress suppressed equine chorionic gonadotrophin (eCG)-induced follicular growth and caused a significant reduction of FSH receptor content in the granulosa cells (Shimizu et al. 2000). These combined findings suggests that heat-stressed follicles lack sufficient FSH stimulation to enhance the aromatase activity owing to decreased $\mathrm{FSH}$ receptor expression, rather than to diminished FSH levels, and that this leads to the observed decrease in oestradiol concentrations.

Another possible mechanism that could explain the heat-induced reduction of oestradiol synthesis is suggested by the finding that androstenedione and oestradiol concentrations within follicular cells derived from the dominant follicle were reduced by heat stress in an in vitro study (Wolfenson et al. 1997). Previous studies had indicated that the concentration of androstenedione is a limiting factor in oestradiol synthesis and follicular growth (Badinga et al. 1992, Savio et al. 1993). It is thus possible that heat stress in vivo causes a similar reduction of androstenedione levels and may consequently limit oestradiol synthesis. Further study to determine the relationship between androstenedione and oestradiol in heat stressed follicles in vivo is required.

Another important finding in the present study was that every follicle exposed to heat stress during recruitment regressed before developing to large size and thus never ovulated, although the number of follicles recruited during the heat-stress period did not differ from the number in control goats (Table 2). This might directly account for the 1-day lag in the development of follicles that eventually ovulated and the $\mathrm{LH}$ surge in heat-stressed goats as 

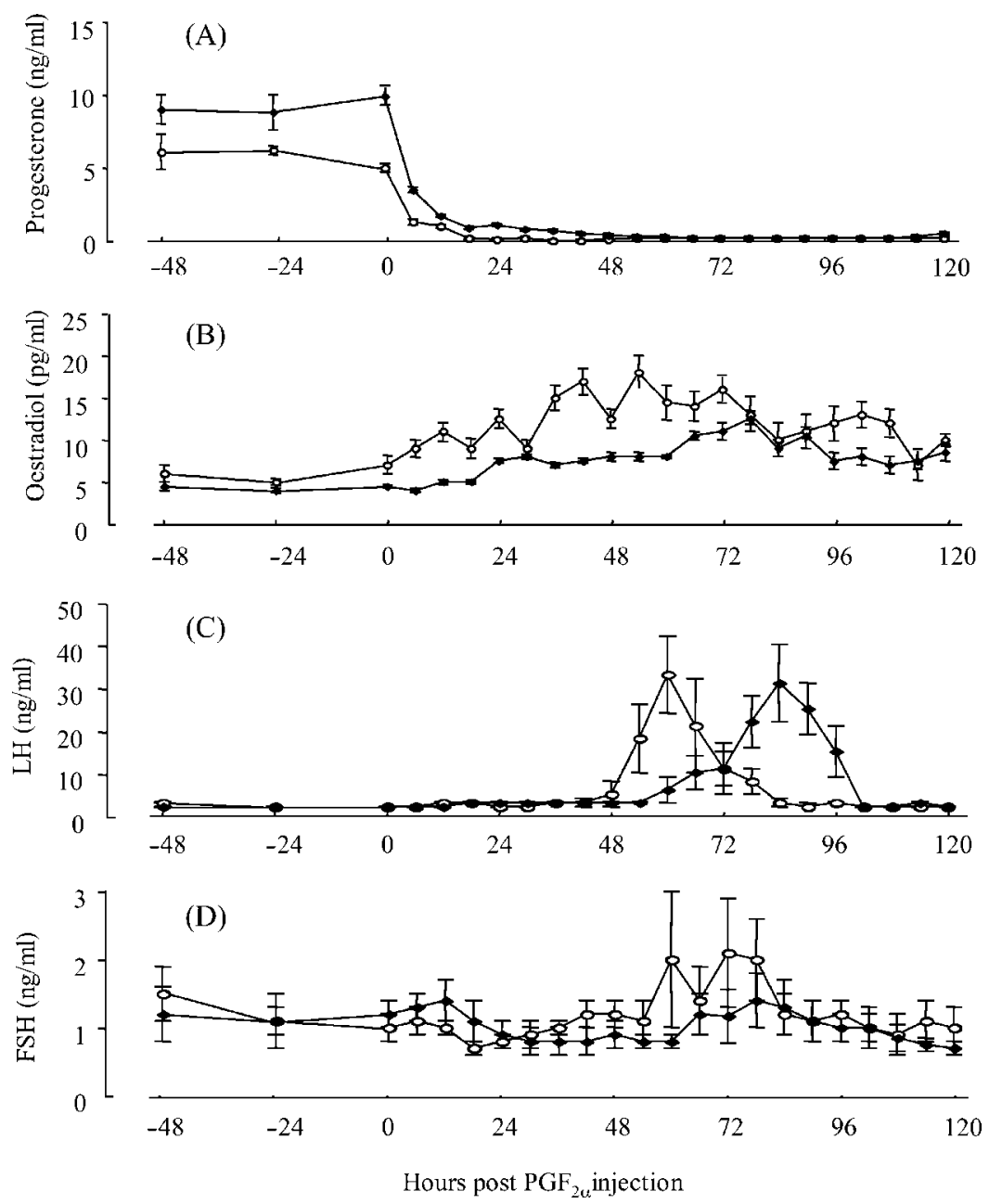

Figure 3 Plasma concentrations of (A) progesterone, (B) oestradiol, (C) LH, and (D) FSH in heat-stressed $(\bullet)$ and control (०) goats from -48 to $120 \mathrm{~h}$. Plasma samples were collected at $24-\mathrm{h}$ intervals from -48 to $0 \mathrm{~h}$ and at $6-\mathrm{h}$ intervals from 0 to $120 \mathrm{~h}$. Values are expressed as means \pm S.E.M. from six replicates.

compared with controls. The timing of the ovulation, however, was not delayed significantly. We collected the blood sample every $6 \mathrm{~h}$ for the LH assay, and ovulation was observed in every 24-h interval. This may be the reason why the time lag of the ovulation could not be traced despite the significant delay of LH surge in this study.
Follicular recruitment and differentiation are induced by exposure of FSH (Fortune 1994, Garverick et al. 2002), and then gonadotrophin dependent for further follicular growth is transferred from FSH to LH (Webb et al. 2003). $\mathrm{LH}$ regulates the progression of medium follicles to large follicles (Savio et al. 1993, Webb et al. 1994), as well as follicular dominance (Bodensteiner et al. 1996) in cows.

Table 3 Characteristics of pulsatile LH secretion in intact goat or steroid-implanted OVX goat under control and heat-stress conditions. Data are expressed as the mean \pm S.E.M. of six replicates.

\begin{tabular}{lllccc}
\hline & & & \multicolumn{2}{c}{ OVX goat } \\
\cline { 4 - 6 } & Treatment & Intact goat & Without steroids & E implantation & E + P implantation \\
\hline Frequency $($ pulse/4h) & Control & $3.50 \pm 1.64$ & $6.89 \pm 0.78$ & $3.89 \pm 0.78$ & $1.56 \pm 0.44$ \\
& Heat stress & $2.50 \pm 0.29$ & $6.44 \pm 0.67$ & $3.89 \pm 0.56$ & $1.78 \pm 0.33$ \\
Amplitude $(\mathrm{ng} / \mathrm{ml})$ & Control & $1.80 \pm 0.38$ & $1.67 \pm 0.83$ & $2.11 \pm 0.22$ & $1.44 \pm 0.33$ \\
& Heat stress & $1.53 \pm 0.21$ & $1.22 \pm 0.19$ & $1.80 \pm 0.37$ & $1.61 \pm 0.13$ \\
Basal $(\mathrm{ng} / \mathrm{ml})$ & Control & $1.61 \pm 0.57$ & $1.61 \pm 0.57$ & $0.72 \pm 0.12$ & $0.33 \pm 0.18$ \\
& Heat stress & $1.72 \pm 0.28$ & $1.72 \pm 0.28$ & $1.00 \pm 0.12$ & $0.28 \pm 0.09$ \\
\hline
\end{tabular}



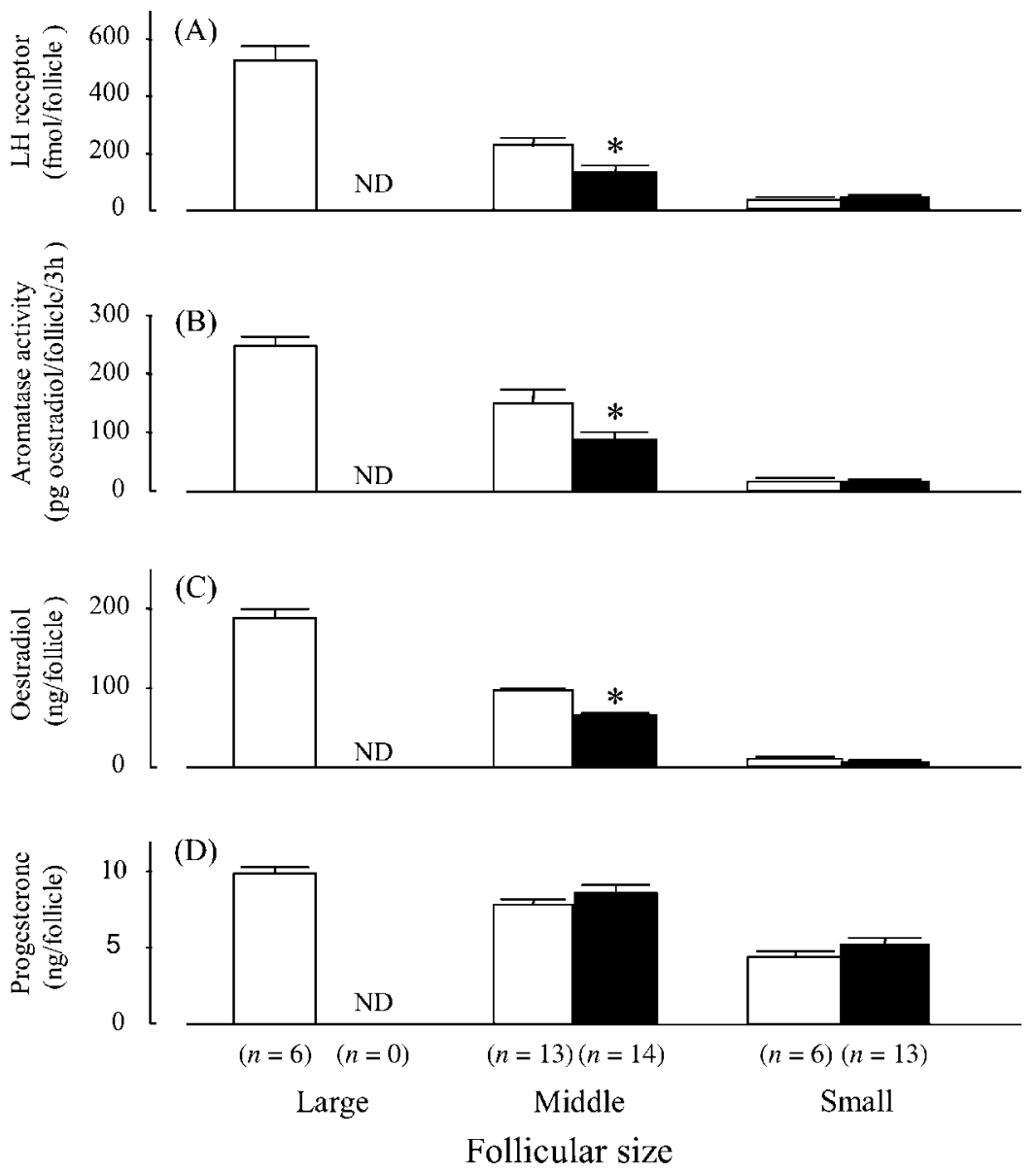

Figure 4 Effects of heat stress on (A) LH receptor, (B) aromatase activity, $(\mathrm{C})$ oestradiol concentration, and (D) progesterone concentration in follicles of each size category from heat-stressed ( $\square$ ) and control ( $\square$ ) female goats. The follicular development was monitored during the experimental period, and ovaries were recovered from four goats in each group at $48 \mathrm{~h}$ post $\mathrm{PGF}_{2 \alpha}$ injection. Every follicle recruited from -24 to $0 \mathrm{~h}$ was collected from the ovaries, categorized by size (small, 2.0-3.4 mm; medium, $3.5-4.9 \mathrm{~mm}$; large, $>5 \mathrm{~mm}$ ), and analyzed. Values are expressed as the means \pm S.E.M. *Significantly different from follicles of the same size from the controls $(P<0.05)$. ND, no data due to heatstressed follicles not reaching the large size (see text).
In addition, pulsatile LH secretions are known to drive follicular steroidogenesis directly since the follicle become oestrogenic (Baird 1983). Several stressors such as insulininduced hypoglycemia (Medina et al. 1998) or endotoxin injection (Battaglia et al. 1997) are known to cause a decrease in $\mathrm{LH}$ pulse frequency. The present results also indicated that the number of $\mathrm{LH}$ pulses tended to decrease in intact goats due to heat stress (3.5 times in controls versus 2.5 times in heat stress). Therefore, the reduced stimulation of the growing follicle by $\mathrm{LH}$, due to heat stress, could be a cause of follicular atresia. In contrast, our present data also indicated that no significant differences in the characteristics in $\mathrm{LH}$ pulse were detected between heat stress and control in OVX goats regardless of whether ovarian steroid(s) were implanted or not. These results suggest that the effect of heat stress in the present study was minimal to disturb the $\mathrm{GnRH}$ pulse generator. Previously, Kanai et al. (1995) demonstrated in long-day-treated anoestrous goats that heat stress prevented the increase in plasma oestradiol concentration and the $\mathrm{LH}$ surge induced by exogenous $\mathrm{GnRH}$ injection, although the frequency of $\mathrm{LH}$ pulses did not change due to heat stress, indicating that heat stress reduced follicular responsiveness to $\mathrm{LH}$. In the present study we have shown direct evidence that the expression of $\mathrm{LH}$ receptor in heatstressed follicles was decreased. Taken together, these findings suggest that follicular responsiveness to $\mathrm{LH}$ is suppressed by heat stress and that heat-stressed follicles thus lack sufficient LH stimulation, leading to regression of the follicles before ovulation. Further studies investigating the mechanisms that block $\mathrm{LH}$ receptor expression during heat stress are required.

A significant reduction of feed intake during heat stress was also observed in this study. Prolonged energy imbalance is also an indirect factor that can alter follicular growth (Lucy et al. 1992, Butler 2001, Roche \& Diskin 2001). However, the duration of the heat stress in this study was $48 \mathrm{~h}$, and every parameter we monitored to determine the general response to heat stress did not differ between the two groups before and after the period of heat stress. Therefore, the indirect effects of energy imbalance were likely to be minimal compared with the direct influences of heat stress on follicular function. In conclusion, heat stress during recruitment severely compromises follicular growth from medium size to ovulation and these effects are associated with suppressed oestradiol and $\mathrm{LH}$ receptor levels.

\section{Acknowledgements}

We thank the National Hormone and Pituitary Program of the NIAMDD for $\mathrm{LH}$ and $\mathrm{FSH}$ radioimunoassay kits, Dr $\mathrm{Y}$ Mori 
for the LH antiserum (YM-18) and for his technical advice on the steroid implantation, and Ms K. Neath for the grammatical correction. This work was supported by a Grant-in-Aid for Exploratory Research (no. 16658102) from the Japan Society for the Promotion of Science to Y K. The authors declare that there is no conflict of interest that would prejudice the impartiality of this scientific work.

\section{References}

Al-Katanani YM, Paula-Lopes FF \& Hansen PJ 2001 Effect of season and exposure to heat stress on oocyte competence in Holstein cows. Journal of Dairy Science 85 390-396.

Araki K, Araki YK, Watanabe G \& Taya K 2000 Involvement of inhibin in the regulation of follicle-stimulating hormones secretion in the young adult male Shiba goat. Journal of Andrology 21 558-565.

Badinga L, Driancourt MA, Savio JD, Wolfenson D, Drost M, De La Sota RL \& Thatcher WW 1992 Endocrine and ovarian responses associated with the first-wave dominant follicle in cattle. Biology of Reproduction 47 871-883.

Badinga L, Thatcher WW, Diaz T, Drost M \& Wolfenson D 1993 Effect of environmental heat stress on follicular development and steroidogenesis in lactating Holstein cows. Theriogenology 39 797-810.

Baird DT 1983 Factors regulating the growth of the preovulatory follicle in the sheep and human. Journal of Reproduction and Fertility $69343-352$.

Battaglia DF, Bowen JM, Krasa HB, Thrun LA, Viguie C \& Karsch FJ 1997 Endotoxin inhibits the reproductive neuroendocrine axis while stimulating adrenal steroids: a simultaneous view from hypophyseal portal and peripheral blood. Endocrinology 138 4273-4281.

Berman A, Folman Y, Kaim M, Mamen M, Herz Z, Wolfenson D, Arieli A \& Graber Y 1985 Upper critical temperatures and forced ventilation effects for high-yielding dairy cows in a subtropical climate. Journal of Dairy Science 68 1488-1495.

Bodensteiner KJ, Wiltbank MC, Bergfelt DR \& Ginther OJ 1996 Alternations in follicular estradiol and gonadotropin receptors during development of bovine antral follicles. Theriogenology $\mathbf{4 5}$ 499-512.

Butler WR 2001 Nutritional effects on resumption of ovarian cyclicity and conception rate in postpartum dairy cows. In Fertility in the High-Producing Dairy Cow, vol. 26, pp 133-145. Ed. MG Diskin. Edinburgh: BSAS Occasional Publication.

Carson RS, Findlay JK, Burger HG \& Trounson AO 1979 Gonadotropin receptors of the ovine follicle during follicular growth and atresia. Biology of Reproduction 21 75-87.

de Castro T, Rubianes E, Menchaca A \& Rivero A 1999 Ovarian dynamics, serum estradiol and progesterone concentrations during the interovulatory interval in goat. Theriogenology 52 399-411.

Dorrington JH, Moon YS \& Armstrong DT 1975 Estradiol-17 $\beta$ biosynthesis in cultured granulosa cells from hypophysectomized immature rats: stimulation by follicle stimulating hormone. Endocrinology 97 1328-1331.

Ealy AD, Drost M \& Hansen PJ 1993 Developmental changes in embryonic resistance to adverse effects of maternal heat stress in cows. Journal of Dairy Science 76 2899-2905.

Erickson GF \& Hsufh AJW 1978 Stimulation of aromatase activity by follicle stimulating hormone in rat granulosa cells in vivo and in vitro. Endocrinology 102 1275-1282.

Fortune JE 1994 Ovarian follicular growth and development in mammals. Biology of Reproduction 50 225-232.

Fortune JE, Sirois J, Turzillo AM \& Lavoir M 1991 Follicular selection in domestic ruminants. Journal of Reproduction and Fertility 43 (suppl) 187-198.

Garverick HA, Baxter G, Gong J, Armstrong DG, Campbell BK, Gutierrez CG \& Webb R 2002 Regulation of expression of ovarian
mRNA encoding steroidogenic enzymes and gonadotrophin receptors by $\mathrm{FSH}$ and $\mathrm{GH}$ in hypogonadotrophic cattle. Reproduction $123651-661$.

Gill JL \& Hafs HD 1971 Analysis of repeated measurements of animals. Journal of Animal Science 33 331-336.

Griffin PG \& Ginther OJ 1992 Research applications of ultrasonic imaging in reproductive biology. Journal of Animal Science $\mathbf{7 0}$ 953-972.

Gwazdauskas FC, Wilcox CJ \& Thatcher WW 1975 Environmental and managemental factors affecting conception rate in a subtropical climate. Journal of Dairy Science 58 88-92.

Gwazdauskas FC, Thatcher WW, Kiddy CA, Paape MJ \& Wilcox CJ 1981 Hormonal pattern during heat stress following tham salt induced luteal regression in heifers. Theriogenology $\mathbf{1 6}$ 271-285.

Hansen PJ \& Aréchiga CF 1999 Strategies for managing reproduction in the heat-stressed dairy cow. Journal of Dairy Science $\mathbf{8 2}$ (suppl 2) 36-50.

Hansen PJ, Drost M, Rivera RM, Paula-Lopes FF, Al-Katanani YM, Krininger CE III \& Chase CC Jr 2001 Adverse impact of heat stress on embryo production: causes and strategies for mitigation. Theriogenology 55 91-103.

Ingraham RH, Gillette DD \& Wagner WD 1974 Relationship of temperature and humidity to conception rate of Holstein cows in a subtropical climate. Journal of Dairy Science 57 476-481.

Kanai Y, Yagyu N \& Shimizu T 1995 Hypogonadism in heat stressed goats: poor responsiveness of the ovary to the pulsatile LH stimulation induced by hourly injections of a small dose of $\mathrm{GnRH}$. Journal of Reproduction and Development 41 133-139.

Kawate N, Inaba T \& Mori J 1989 Number of gonadotropin receptors and concentrations of steroid hormones in bovine follicles. Japanese Journal of Animal Reproductive Technology 35 106-111.

Lucy MC, Savio JD, Badinga L, De La Sota RL \& Thatcher WW 1992 Factors that affect ovarian follicular dynamics in cattle. Journal of Animal Science 70 3615-3626.

Madan ML \& Johnson HD 1973 Environmental heat effects on bovine luteinizing hormone. Journal of Dairy Science $\mathbf{5 6}$ $1420-1423$.

McNatty KP, Heath DA, Henderson KM, Lun S, Hurst PR, Ellis LM, Montgomery GW, Morrison L \& Thurley DC 1984 Some aspects of thecal and granulose cell function during follicular development in the bovine ovary. Journal of Reproduction and Fertility $\mathbf{7 2}$ $39-53$

Medan MS, Watanabe G, Sasaki K, Sharawy S, Groome NP \& Taya K 2003 Ovarian dynamics and their associations with peripheral concentrations of gonadotropins, ovarian steroids, and inhibin during the estrous cycle in goats. Biology of Reproduction 69 $57-63$.

Medina CL, Nagatani S, Darling TA, Bucholtz DC, Tsukamura H, Maeda KI \& Foster DL 1998 Glucose availability modulates the timing of the luteinizing hormone surge in the ewe. Journal of Neuroendocrinology 10 785-792.

Menchaca A \& Rubianes E 2002 Relation between progesterone concentrations during the early luteal phase and follicular dynamics in goats. Theriogenology 57 1411-1419.

Merriam GR \& Wachter KW 1982 Algorithms for the study of episodic hormone secretion. American Journal of Physiology Endocrinology and Metabolism 243 E310-E318.

Miller HL \& Alliston CW 1974 Influence of programmed circadian temperature changes upon levels of luteinizing hormone in the bovine. Biology of Reproduction 11 187-190.

Mori Y \& Kano Y 1984 Changes in plasma concentrations of LH, progesterone and estradiol in relation to the occurrence of luteolysis, estrus and time of ovulation in Shiba goats (Capra hircus). Journal of Reproduction and Fertility 72 223-230.

Ozawa M, Hirabayashi M \& Kanai Y 2002 Developmental competence and oxidative state of murine zygotes heat stressed maternally or in vitro. Reproduction 124 683-689. 
Ravindra JP, Rawlings NC, Evans ACO \& Adams GP 1994 Ultrasonographic study of ovarian follicular dynamics in ewes during the oestrus cycle. Journal of Reproduction and Fertility 101 501-509.

Rensis FD \& Scaramuzzi RJ 2003 Heat stress and seasonal effects on reproduction in the dairy cow-a review. Theriogenology 60 $1139-1151$.

Robert GC, Heather M \& Dorrington J 1980 An alternative method for the study of follicle-stimulating hormone effects on aromatase activity in sertoli cell cultures. Endocrinology 107 464-471.

Roche JF \& Diskin MG 2001 Resumption of reproductive activity in the early post-partum period of cows. In Fertility in the High-Producing Dairy Cow, vol. 26, pp 31-42. Ed. MG Diskin. Edinburgh: BSAS Occasional Publication.

Roman-Ponce H, Thatcher WW \& Wilcox CJ 1981 Hormonal interrelationships and physiological responses of lactating dairy cows to shade management system in a tropical environment. Theriogenology 16 139-154.

Rosenberg M, Folman Y, Herz Z, Flamenbaum I, Berman A \& Kaim M 1982 Effect of climatic conditions on peripheral concentrations of $\mathrm{LH}$, progesterone and estradiol-17 $\beta$ in high milk-yielding cows. Journal of Reproduction and Fertility 66 139-146.

Roth Z, Meidan R, Braw-Tal R \& Wolfenson D 2000 Immediate and delayed effects of heat stress on follicular development and its association with plasma FSH and inhibin concentration in cows. Journal of Reproduction and Fertility 120 83-90.

Savio JD, Thatcher WW, Badinga L, de la Sota RL \& Wolfenson D 1993 Regulation of dominant follicle turnover during the oestrous cycle in cows. Journal of Reproduction and Fertility $\mathbf{9 7}$ 197-203.

Shimizu T, Ohshima I, Tajima A \& Kanai Y 2000 Effect of heat stress on follicular development in PMSG-treated immature rats. Animal Science Journal 71 32-37.

Tanaka T, Mori Y \& Hoshino K 1994 Long-term recording of hypothalamic $\mathrm{GnRH}$ pulse generator activity during programmed administration of progesterone and estradiol in the ovariectomized goat. Journal of Reproduction and Development $40183-188$.

Thatcher WW, Driancourt DD, Terqui M \& Badinga L 1991 Dynamics of ovarian follicular development in cattle following hysterectomy and during early pregnancy. Domestic Animal Endocrinology 8 223-234.

Trout JP, McDowell LR \& Hansen PJ 1998 Characteristics of the estrous cycle and antioxidant status of lactation Holstein cows exposed to heat stress. Journal of Dairy Science $\mathbf{8 1}$ $1244-1250$.

Udompraset P \& Williamson NB 1987 Seasonal influences on conception efficiency in Minnesota dairy herds. Theriogenology $\mathbf{2 8}$ 323-336.

Webb R \& England BG 1982 Relationship between LH receptor concentration in thecal and granulose cells and in vivo and in vitro follicles during the preovulatory period. Journal of Reproduction and Fertility 66 169-180.

Webb R, Gong JG \& Bramley TA 1994 Role of growth hormone and intrafollicular peptides in follicle development in cattle. Theriogenology 41 25-30.

Webb R, Nicholas B, Gong JG, Campbell BK, Gutierrez CG, Garverick HA \& Armstrong DG 2003 Mechanisms regulating follicular development and selection of the dominant follicle. Reproduction 61 suppl 71-90.

Wilson SJ, Kirby CJ, Koenigsfeld DH, Keisler DH \& Lucy MC 1998a Effects of controlled heat stress on ovarian function of dairy cattle. 2. Heifers. Journal of Dairy Science $812132-2138$.

Wilson SJ, Marion RS, Spain JN, Spiers DE, Keisler DH \& Lucy MC $1998 b$ Effects of controlled heat stress on ovarian function of dairy cattle. 1. Lactating cows. Journal of Dairy Science 81 2124-2131.

Wolfenson D, Thatcher WW, Badinga L, Sovio JD, Meidan R, Lew BJ, Braw-tal R \& Berman A 1995 Effect of heat stress on follicular development during the estrous cycle in lactating dairy cattle. Biology of Reproduction 52 1106-1113.

Wolfenson D, Lew BJ, Thatcher WW, Graber Y \& Meidan R 1997 Seasonal and acute heat effects on steroid production by dominant follicles in cow. Animal Reproduction Science 47 9-19.

Wolfenson D, Roth Z \& Meidan R 2000 Impaired reproduction in heat-stressed cattle: basic and applied aspects. Animal Reproduction Science 60-61 535-547.

Zeron Y, Ocheretny A, Kedar O, Borochov A, Sklan D \& Arav A 2001 Seasonal changes in bovine fertility: relation to developmental competence of oocytes, membrane properties and fatty acid composition of follicles. Reproduction 121 447-454.

Received 19 August 2004

First decision 21 September 2004

Revised manuscript received 16 December 2004

Accepted 21 December 2004 